\title{
Investigation of Adaptation to Successive Postural Perturbations in Patients with Multiple Sclerosis
}

\author{
Multipl Sklerozlu Hastalarda Ardışık Postural Pertürbasyonlara Adaptasyonun \\ Değerlendirilmesi
}

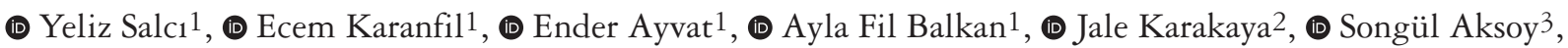 \\ (1) Kadriye Armutlu ${ }^{1}$, (1) Asl Tuncer $^{4}$, (1) Rana Karabudak ${ }^{4}$ \\ 1Hacettepe University Faculty of Physical Therapy and Rehabilitation, Ankara, Turkey \\ 2Hacettepe University Faculty of Medicine, Department of Biostatistics, Ankara, Turkey \\ 3Hacettepe University Faculty of Health Sciences, Department of Audiology, Ankara, Turkey \\ 4Hacettepe University Faculty of Medicine, Department of Neurology, Ankara, Turkey
}

\begin{abstract}
Objective: It is well known that abnormal automatic postural responses impair balance control in patients with multiple sclerosis (PwMS) and these responses can be ameliorated with training. However, the difference between patients with MS and the healthy population on the adaptation capacity of postural responses to perturbations remains unclear. The aim of the present study was to evaluate the adaptation capability to postural perturbations in PwMS and to reveal differences between healthy controls.

Materials and Methods: Sixty-nine ambulatory PwMS with Expanded Disability Status Scale (EDSS) scores below or equal to 5.5 , and 61 healthy subjects were recruited for the study. Adaptation Test with NeuroCom Smart Balance Master System, Berg Balance Scale (BBS), and EDSS were administered. The adaptation test was performed in the toes-up and toes-down directions; five consecutive perturbations were given for each direction. The sway energy score was calculated for postural sway that were released during these perturbations.

Results: According to the adaptation test results, healthy volunteers' sway energy scores were significantly lower than those of PwMS in five consecutive perturbations (toes-up $\mathrm{p}<0.001$, toes-down $\mathrm{p}<0.001$ ). Healthy volunteers and PwMS were adapted in trial 3 for both directions and sway energy score changes in time were found similar between the groups. The toes-up adaptation rate in PwMS (17\%) was statistically lower than in healthy group ( $31 \%)(\mathrm{p}=0.026)$, and the toes-down adaptation rate was similar $(\mathrm{p}=0.175)$. The BBS and EDSS had significant correlations with average toes-up sway energy scores $(\mathrm{r}=-0.402, \mathrm{r}=0.392$, respectively).

Conclusion: Ambulatory PwMS have preserved adaptation to automatic postural responses, with higher sway energy scores. A low adaptation rate in the toes-up direction should be taking into account when planning the motor strategy training.
\end{abstract}

Keywords: Multiple sclerosis, automatic postural responses, adaptation, fall risk

\section{$\ddot{O} \mathbf{z}$}

Amaç: Anormal otomatik postural yanıtların multipl sklerozlu (MS) bireylerde denge kontrolünü bozduğu ve bu anormal yanıtların eğitim ile iyileştirilebileceği iyi bilinmektedir. MS'li bireylerde, otomatik postural yanıtların pertürbasyonlara adapte olma durumunun, sağlıklı bireylerden farkı net değildir. Bu çalışmanın amacı, MS hastalarının postural pertürbasyonlara adaptasyon yeteneğini de ğerlendirmek ve sağlıklı kontroller arasındaki farkları ortaya koymaktır.

Gereç ve Yöntem: Genişletilmiş Engellilik Durum Ölçeği (EDSS) puanı 5.5 ve altında olan 69 MS hastası ve 61 să̆lıklı birey çalışmaya dahil edilmiştir. NeuroCom Smart Balace Master sistem ile adaptasyon testi, Berg Denge Ölçeği (BBS) ve EDSS uygulanmıştır. Adaptasyon testi ile toes up (geriye) ve toes-down (öne) yönlerinde, her bir yön için 5 deneme olacak sekilde ardı sıra pertürbasyonlar verilmiştir. Bu pertürbasyonlar sırasında açığa cıkan postural salınımlar için salınım enerji puanı hesaplanmıştır.

Bulgular: Adaptasyon testi sonuçlarına gore, 5 ardışık pertürbasyonda, să̆lıklı bireylerin salınım enerji puanları MS’li bireylerden anlamlı derecede düşüktür (toes-up p=0,0001, toes-down $\mathrm{p}<0,001$ ). Sağlıklı bireyler ve MS hastaları her iki yönde de 3. denemede adapte olmuşlardır ve salınım enerji puanlarının zaman içerisindeki değişimi gruplarda benzerdir. Toes-up adaptasyon oranı MS'li bireylerde (\%17) sağlıklı bireylerden (\%31) istatistiksel olarak düşük bulunmuştur ( $\mathrm{p}=0,026)$; BBS ve EDSS yalnızca toes-up salınım enerji puanı ile anlamlı korelasyon göstermiştir ( $\mathrm{r}=-0,402$, r: sırasıyla 0,392$)$.

Sonuç: Ambulatuvar MS hastalarında postüral cevapların adaptasyon yeteneği korunmuştur ancak daha yüksek salınım enerji puanları vardır. Motor stratejisi eğitimini planlarken, toes-up yönündeki adaptasyon oranının sağlıklılardan daha düşük olduğu dikkate alınmalıdır.

Anahtar Kelimeler: Multipl skleroz, otomatik postüral yanıtlar, adaptasyon, düşme riski

\footnotetext{
Address for Correspondence/Yazışma Adresi: Yeliz Salcı MD, Hacettepe University Faculty of Physical Therapy and Rehabilitation, Ankara, Turkey Phone: +90 5303272310 E-mail: fztyeliz@hotmail.com ORCID: orcid.org/0000-0002-3728-7194

Received/Geliş Tarihi: 07.05.2019 Accepted/Kabul Tarihi: 05.12.2019

${ }^{\circ}$ Copyright 2020 by Turkish Neurological Society

Turkish Journal of Neurology published by Galenos Publishing House.
} 


\section{Introduction}

Multiple sclerosis (MS) is a chronic, inflammatory, and autoimmune disease of the central nervous system (CNS). Demyelinated plaques in the CNS, which disseminate spatially and temporally, cause neurologic signs and symptoms $(1,2)$. Postural control problems are some of the most debilitating symptoms, which have various mechanisms due to the involvement of many parts of CNS in patients with MS (PwMS) (2). The main postural control problems are reported as: difficulty in maintaining positional stability, limited and slowed movement toward limits of stability, poorer trunk control, and delayed automatic postural responses to external perturbations (3).

Automatic postural responses are defined as the primary component of postural control to recover upright body balance following a sudden perturbation such as a slip or trip. They can be mechanically elicited by perturbing the base of support under the body's centre of mass with a moving force plate $(4,5,6,7)$. A normal response involves activation of particular muscle groups with an appropriate response amplitude and onset latencies (8). The reduction of magnitude of reactions with the repetition of perturbation is called adaptation and it is critical for postural control $(9,10,11)$.

Previous studies have indicated that PwMS have difficulties mostly in perturbed balance tests and perturbed tests have proven to be more sensitive at revealing postural control problems $(12,13,14,15)$. Delayed onset in postural responses has also been reported in perturbed tests, and these delayed responses were explained by prolongation of somatosensory evoked potential latencies $(14,16,17,18,19)$. Pratt et al. (20) reported that delayed postural responses latencies were compensated by increasing the magnitude of responses and using more compensatory control. Many studies also demonstrated that PwMS had reduced magnitude/delayed onset of anticipatory postural adjustments, and increased compensatory COP displacements compared with healthy subjects $(21,22)$.

The phenomenon of adaptation was studied in detail in healthy subjects and in patients with Parkinson's disease $(23,24,25,26,27,28)$. Despite the large body of studies on postural control, balance, centre of pressure changes using a force plate, very few reports are available on the adaptation to postural responses in PwMS. A small sample size study reported that PwMS had similar postural adaptation to age-matched healthy control participants (29). In the present study, we sought to evaluate the adaptation capability of postural perturbations in PwMS.

\section{Materials and Methods}

This cross-sectional study was conducted in Hacettepe University, Physical Therapy and Rehabilitation Department, Dizziness and Balance Disorders Research and Application Center, Turkey. The local ethics committee of Hacettepe University NonInterventional Ethics Committee approved the study (approval no: GO 17/637-32). All patients and healthy volunteers gave written informed consent according to the Declaration of Helsinki.

\section{Participants}

Seventy-three PwMS were included in the study with the following eligibility criteria: MS diagnosed by a neurologist and aged between 18-59 years; able to walk at least 100 meters without aid or rest; having an Expanded Disability Status Scale (EDSS) score below or equal to 5.5. The exclusion criteria of the study were having accompanying neurologic, orthopaedic, systemic disease; having a peripheral vestibular balance disorder; have previously performed adaptation test; and being in an acute exacerbation period.

Sixty-one healthy volunteers were recruited with the following criteria: no current or past medical diagnosis or injuries affecting balance; no medications affecting the CNS or known to affect balance/coordination; no symptoms of dizziness or lightheadedness; no symptoms suggestive of vestibular or neurologic disorders; no history of two or more unexplained falls within the past 6 months.

\section{Assessments}

The patients' demographic data [age, sex, body mass index (BMI)], course of disease (MS type, MS duration, time elapsed between the acute exacerbation and assessments) were recorded.

EDSS: The EDSS is a quantitative rating scale of disability in PwMS. Eight functional systems are assessed and disability is graded between 0-10 according to these functional system scores. Higher scores indicate higher disability levels (30). Patients' EDSS assessments were performed by a licensed and experienced physiotherapist (Y.S.).

Adaptation test: This test is part of computerized dynamic posturography (CDP-Neuro-Com International, Inc., Clackamas, 108 OR, USA), which assesses the patients' automatic postural responses and ability to minimize the centre of gravity (COG) sway during the recovery period following a support surface rotation. The support surface rotates with toes-up ( 5 trials) and toes-down ( 5 trials) directions, successively, and always in the same order. The test does not get progressively more difficult (i.e. it is the same perturbation every trial). After the first 5 trials, instruct the participant that the platform will now move in the opposite direction, rotating downward.

The sway energy score, which is a quantitative measure of magnitude of COG sway, was obtained for each of the five rotations and each direction. The sway energy score is a weighted sum of the root mean square COG sway velocity and sway acceleration measure over 2-5 second interval immediately following rotation. Lower scores reflect good performances (31). The percentage of the sway energy scores' decline (adaptation rate) trial was calculated when comparing the average of the first and last trials.

Berg Balance Scale (BBS): This scale assesses dynamic and static balance with 14 performance-based items. Lower scores indicate poor balance. It is widely used in clinical practice for measuring fall risk and is also a reliable and a valid test in PwMS $(32,33,34)$.

\section{Statistical Analysis}

Statistical analyses were performed using the IBM SPSS Statistics software (version 23; IBM, Armonk; NY, USA). Continuous variables are expressed as mean \pm standard deviation (SD) or as medians (minimum-maximum); categorical variables are expressed as frequencies and percentages. Student's t-test was used to compare age, BMI means, and adaptation rates. The paired t-test was used to compare toes-up and toes-down rotation sway 
energy scores. Two-way repeated measures analysis of variance (ANOVA) was used to compare adaptation test results. ANOVA was performed with between-factor groups (MS group vs. healthy control group), within-factor trials ( 5 trial), and Huynh-Feld adjustment was used when sphericity was violated. A Bonferroni multiple comparisons post hoc test was performed to determine the significantly different pairwise. Pearson's correlation coefficient test was used to find the relationship between the clinical scales and postural responses. $\mathrm{P}<0.05$ was accepted as statistically significant.

\section{Results}

Seventy-three PwMS met the inclusion criteria. Four were excluded from the analyses because they had fall scores in all the trials. In total, 69 PwMS and 61 healthy volunteers were recruited, and their results were analysed. There were no statistically significant differences between the groups in terms of age, BMI or sex $(\mathrm{p}>0.05)$ (Table 1$)$.

\section{Toes-up}

Five sway energy scores obtained from five consecutive toes-up rotations of base of support were compared between the groups. The two-way ANOVA demonstrated a statistically significant difference between the trials (effect size, eta squared: 0.239, $\mathrm{p}<0.001$ ) and for the groups (observed power: 93\%, effect size, eta squared: $0.086 \mathrm{p}=0.001$ ), but no statistically significant difference was found for group $\mathrm{x}$ time interaction (effect size, eta squared: $0.007, \mathrm{p}=0.389$ ). This means that $\mathrm{PwMS}$ and the healthy volunteers' responses were similar to the consecutive toes-up perturbations. However, healthy volunteers had lower sway energy scores than PwMS (Table 2).

Multiple comparisons with Bonferroni demonstrated that PwMS had similar sway energy scores in trials 3, 4, and 5. That means PwMS habituated in trial 3. Likewise, healthy volunteers' sway energy scores in trials 3, 4, and 5 were similar, and they also habituated in trial 3 (Figure 1).

\section{Toes-down}

A significant decrease in toes-down sway energy scores were found (effect size: 0.218, p<0.001) in both groups. Healthy volunteers' sway energy scores were significantly lower than PwMS (observed power 99\%, effect size, eta squared: 0.178 $\mathrm{p}<0.001)$. Sway energy score changes in time were found similar between the groups (effect size, eta squared: 0.016, $\mathrm{p}=0.114$ ) (Table 2). According to pairwise comparisons of the groups, these differences were seen in all trials. Pairwise comparisons within groups demonstrated that both groups habituated in trial 3 (Figure 2).

Table 1. Demographic characteristics of the patients with multiple sclerosis and healthy subjects

\begin{tabular}{|c|c|c|c|}
\hline & $\begin{array}{l}\text { MS group } n=69 \\
(\text { mean } \pm S D)\end{array}$ & $\begin{array}{l}\text { Control group } n=61 \\
(\text { mean } \pm S D)\end{array}$ & $\mathrm{p}$ value \\
\hline Age (year) & $35.79 \pm 9.31$ & $33.77 \pm 10.25$ & 0.240 \\
\hline BMI $\left(\mathrm{kg} / \mathrm{m}^{2}\right)$ & $22.85 \pm 3.65$ & $23.95 \pm 3.62$ & 0.086 \\
\hline Disease duration (year) & $7.29 \pm 5.95$ & - & - \\
\hline EDSS 2 & $1(1.4)$ & & \\
\hline EDSS 2.5 & $3(4.3)$ & & \\
\hline EDSS 3 & $23(33.3)$ & & \\
\hline EDSS 3.5 & $27(39.1)$ & & \\
\hline
\end{tabular}

Table 2. Comparison of sways energy scores of adaptation test between groups and sway energy score changes in time

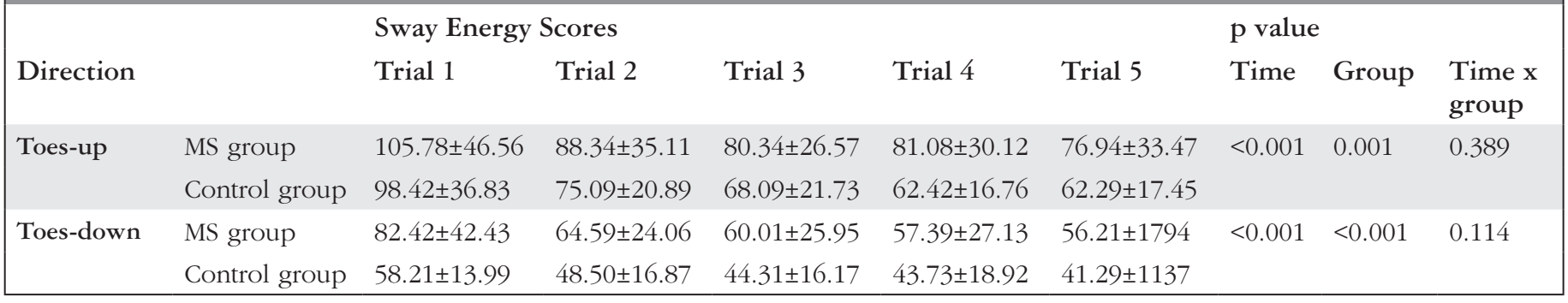




\section{Adaptation Rate}

The adaptation rate (the percentage of decline) in toes-down was $23.45 \pm 24.65 \%$ in PwMS, and $28.16 \pm 13.62 \%$ in healthy subjects. The toes-down adaptation rate was similar between the groups $(\mathrm{p}=0.175)$. The toes-up adaptation rate was $31.13 \pm 22.21 \%$ in healthy subjects, $17.39 \pm 44.73$ in PwMS, which was statistically different ( $\mathrm{p}=0.026)$ (Table 3).

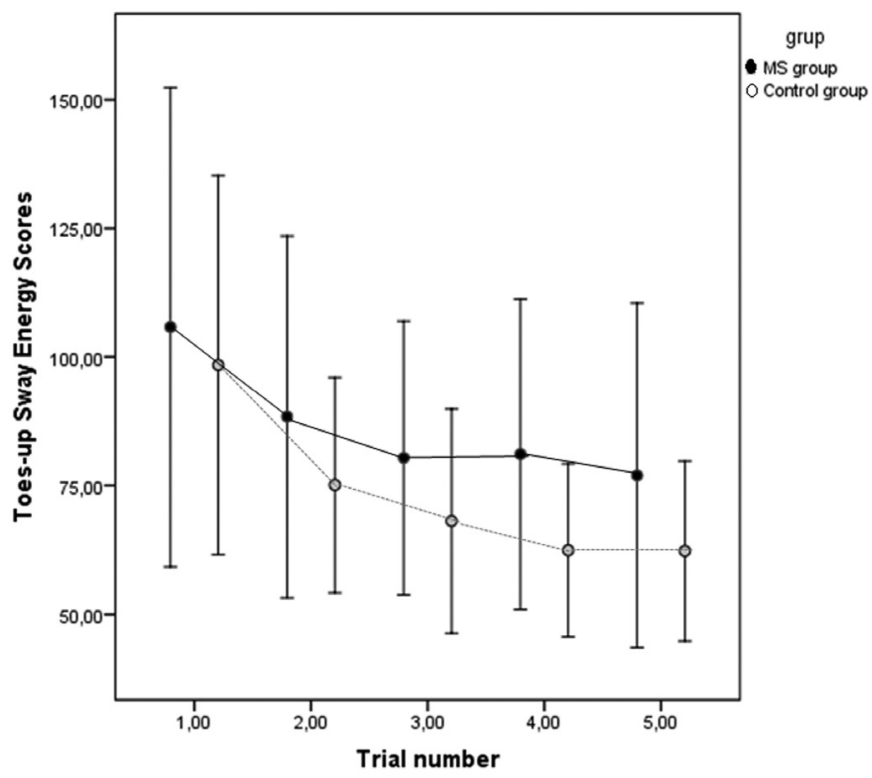

Figure 1. Toes up sway energy scores

MS: Multiple sclerosis

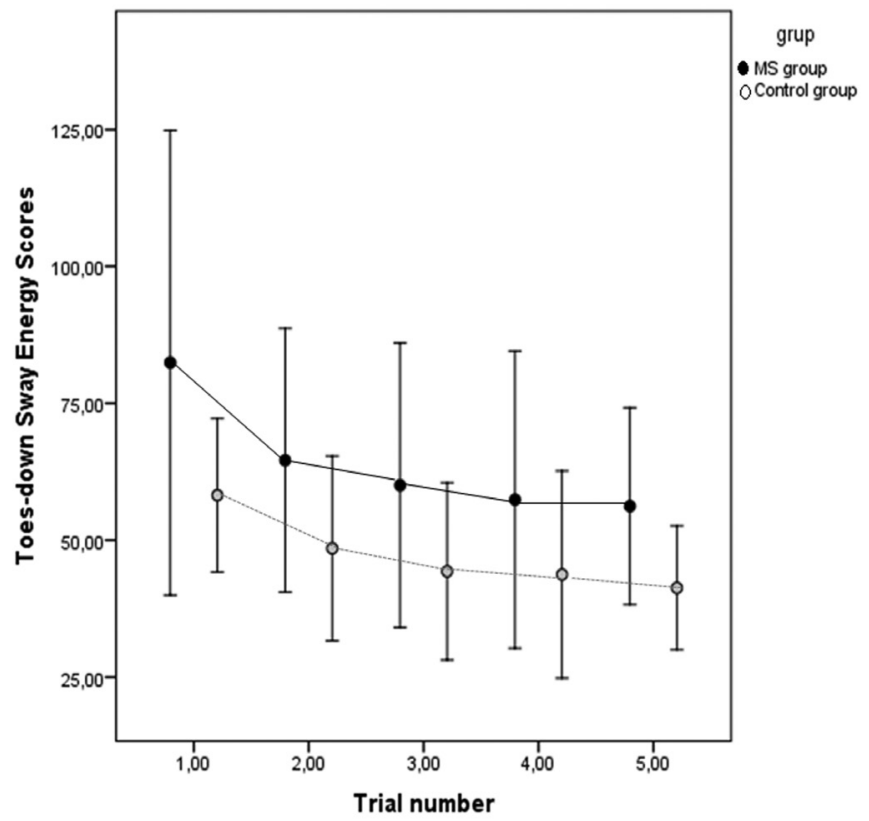

Figure 2. Toes down sway energy scores

MS: Multiple sclerosis

\section{EDSS and BBS}

According to the Pearson correlation analyses, the average sway energy score of toes-up (means of 5 trials) was found to be moderately correlated with BBS $(\mathrm{r}=-0.402, \mathrm{p}=0.001)$. A similar correlation was found between EDSS and toes-up average sway energy score $(r=0.392, p=0.001)$, but the average toes-down sway energy scores were not significantly correlated $(r=0.084, p=0.495)$.

\section{Discussion}

The present cross-sectional study has potentially useful findings and these can be stated as follows; PwMS have higher sway energy scores than healthy subjects who indicate poor postural control. Sway energy scores' changes in time were similar between the groups and both groups adapted in trial 3 with in toes-down and toes-up directions. Moreover, PwMS habituate to toes-up direction with more difficulty compared with healthy controls (17\% vs. $31 \%)$. BBS and EDSS are significantly correlated with toes-up total sway energy scores.

The impairment in postural control does not mean the same as impairment in adaptation capability. Adaptation capability may be preserved despite the poor postural control. Studies suggest that the cerebellar-cortical loop is mainly responsible for adapting postural responses based on prior experience and the basal ganglia is responsible for pre-selecting and optimizing postural responses based on the current context (5). Intact adaptation capabilities were reported previously in reaching activity in mildly affected PwMS; the authors postulated that adaptation capability might have affected patients with severe disability $(35,36)$. Although studies reported that PwMS have the capacity to improve the use of a feed-forward postural strategy with training, their response to successive perturbations in a single test session has not yet been studied $(29,37)$. In the current study, we found similar adaptation patterns of postural responses with healthy population. Moreover, they habituate toes-up direction with more difficulty, which has not been reported previously.

Fjeldstad et al. (13) found a significant correlation between the BBS and average toes-up and toes-down sway energy scores. We found a significant correlation only in toes-up average sway energy scores with the BBS and EDSS. Additionally, patients habituate toes-up direction with more difficulty. This may mean that the toes-up test is more sensitive in revealing postural control impairments in PwMS. In Fjeldstad et al's (13) study, all patients' EDSS scores were below 3; we think that postural responses to perturbations might change with disease severity. Albeit indirectly, this directional difference was found in Peterson et al.'s (19) study. They found a significant correlation between backward stepping and disease severity. Although we assessed feet in-place automatic postural responses, which have a different nature from compensatory stepping reactions, we found a correlation with disease severity and toes-up average sway energy scores. This may be the result of backward and toes up perturbations relying more on startle reflex pathways in upper brain stem regions where MS lesions are seen more $(28,38)$.

\section{Study Limitations}

This study has some limitations. Electromyography assessments would strengthen our results. Performing age and a sex-matched 
Table 3. Comparison of average sway energy scores and adaptation rates of the groups

\begin{tabular}{|c|c|c|c|}
\hline & $\begin{array}{l}\text { MS group } n=69 \\
(\text { Mean } \pm S D)\end{array}$ & $\begin{array}{l}\text { Control group } n=61 \\
(\text { Mean } \pm \text { SD) }\end{array}$ & $\mathrm{p}$ value $\mathrm{a}$ \\
\hline Average toes-up & $86.50 \pm 24.66$ & $73.26 \pm 17.62$ & 0.001 \\
\hline p value ${ }^{b}$ & $<0.001$ & $<0.001$ & - \\
\hline Toes-up adaptation rate (\%) & $17.39 \pm 44.73$ & $31.13 \pm 22.21$ & $0.026^{*}$ \\
\hline
\end{tabular}

healthy group comparisons would be more reliable. We had to exclude patients who fell in all trials because there were no usable data. However, the patients should be divided as fallers and nonfallers according to their fall history in daily living. Nevertheless, our study has potential strengths. The patients' disability levels were close to each other, and $90 \%$ of the patients' EDSS scores were between 3 and 4 .

\section{Conclusion}

From a clinical point of view, adaptation capability is an important advantage for rehabilitation. This means that patients are able to adjust their balance against changing environmental demands and this offers physiotherapists a great functional potential to enhance poor postural control. Clinically, low adaptation rate in the toes-up direction should be taken into account when planning motor strategy training. Stabilizing reversal or rhythmic stabilization techniques of Proprioceptive Neuromuscular Facilitation approaches should be applied for motor strategy training and especially posterior perturbations should be preferred. Additionally, muscles on the posterior side of the body are activated in order to regain balance following toesup perturbations. Therefore, strengthening hamstrings, and the paraspinal and gastrocnemius muscles should increase stability in toes-up perturbations.

\section{Ethics}

Ethics Committee Approval: The study was approved by the Hacettepe University Non-Interventional Ethical Committee (approval no: GO 17/637-32).

Informed Consent: Consent form was filled out by all participants.

Peer-review: Externally peer-reviewed.

\section{Authorship Contributions}

Design: Y.S., A.F.B., K.A., Data Collection or Processing: Y.S., E.K., E.A., S.A., A.K., R.K., Analysis or Interpretation: J.K., A.T., Writing: Y.S., A.F.B.

Conflict of Interest: No conflict of interest was declared by the authors.

Financial Disclosure: The authors declared that this study received no financial support.

\section{References}

1. Compston A, Coles A. Multiple sclerosis. Lancet 2008;372:1502-1517.

2. O'Connor P; Canadian Multiple Sclerosis Working Group. Key issues in the diagnosis and treatment of multiple sclerosis An overview. Neurology 2002;59(6 Suppl 3):S1-33.

3. Cameron MH, Lord S. Postural control in multiple sclerosis: implications for fall prevention. Curr Neurol Neurosci Rep 2010;10:407-412.

4. Chen CL, Lou SZ, Wu HW, Wu SK, Yeung KT, Su FC. Effects of the type and direction of support surface perturbation on postural responses. J Neuroeng Rehabil 2014;11:50.

5. Horak FB, Henry SM, Shumway-Cook A. Shumway-Cook, Postural perturbations: new insights for treatment of balance disorders. Phys Ther 1997; 77:517-533.

6. Bloem BR, Visser JE, Allum JH. Posturography. Handbook of Clinical Neurophysiology 2003;1:295-336.

7. Horak FB, Nashner LM. Central programming of postural movements: adaptation to altered support-surface configurations. J Neurophysiol 1986;55:1369-1381.

8. Moore SP, Rushmer DS, Windus SL, Nashner LM. Human automatic postural responses: responses to horizontal perturbations of stance in multiple directions. Exp Brain Res 1988;73:648-658.

9. Nashner LM. Adapting reflexes controlling the human posture. Exp Brain Res 1976;26:59-72.

10. Keshner EA, Allum JH, Pfaltz CR. Postural coactivation and adaptation in the sway stabilizing responses of normals and patients with bilateral vestibular deficit. Exp Brain Res 1987;69:77-92.

11. Macpherson JM. The force constraint strategy for stance is independent of prior experience. Exp Brain Res 1994;101:397-405.

12. Frzovic D, Morris ME, Vowels L. Clinical tests of standing balance: performance of persons with multiple sclerosis. Arch Phys Med Rehabil 2000;81:215-221.

13. Fjeldstad C, Pardo G, Frederiksen C, Bemben D, Bemben M. Assessment of postural balance in multiple sclerosis. Int J MS Care 2009;11:1-5.

14. Jackson RT, Epstein CM, De l'Aune WR. Abnormalities in posturography and estimations of visual vertical and horizontal in multiple sclerosis. Am J Otol 1995; 16:88-93.

15. Grassi L, Rossi S, Studer V, et al. Quantification of postural stability in minimally disabled multiple sclerosis patients by means of dynamic posturography: an observational study. J Neuroeng Rehabil 2017;14:4.

16. Diener HC, Dichgans J, Hülser PJ, Buettner UW, Bacher M, Guschlbauer B. The significance of delayed long-loop responses to ankle displacement for the diagnosis of multiple sclerosis. Electroencephalogr Clin Neurophysiol 1984;57:336-342.

17. Cameron MH, Horak FB, Herndon RR, Bourdette D. Imbalance in multiple sclerosis: a result of slowed spinal somatosensory conduction. Somatosens Mot Res 2008;25:113-122.

18. Williams NP, Roland PS, Yellin W. Vestibular evaluation in patients with early multiple sclerosis. Am J Otol 1997;18:93-100. 
19. Peterson DS, Huisinga JM, Spain RI, Horak FB. Characterization of compensatory stepping in people with multiple sclerosis. Arch Phys Med Rehabil 2016;97:513-521.

20. Pratt C, Horak F, Herndon R. Differential effects of somatosensory and motor system deficits on postural dyscontrol in multiple sclerosis patients. Posture and gait: control mechanisms 1992;2:118-121.

21. Krishnan V, Kanekar N, Aruin AS. Anticipatory postural adjustments in individuals with multiple sclerosis. Neurosci Lett 2012;506:256-260.

22. Aruin AS, Kanekar N, Lee YJ. Anticipatory and compensatory postural adjustments in individuals with multiple sclerosis in response to external perturbations. Neurosci Lett 2015;591:182-186.

23. Nijhuis LBO, Allum JHJ, Borm GF, Honegger F, Overeem S, Bloem BR Directional sensitivity of "first trial" reactions in human balance control. J Neurophysiol 2009;101:2802-2814.

24. Oude Nijhuis LB, Allum JH, Valls-Solé J, Overeem S, Bloem BR. First trial postural reactions to unexpected balance disturbances: a comparison with the acoustic startle reaction. J Neurophysiol 2010;104:2704-2712.

25. Allum JH, Tang KS, Carpenter MG, Oude Nijhuis LB, Bloem BR. Review of first trial responses in balance control: influence of vestibular loss and Parkinson's disease. Hum Mov Sci 2011;30:279-295.

26. Nanhoe-Mahabier W, Allum JH, Overeem S, Borm GF, Oude Nijhuis LB, Bloem BR. First trial reactions and habituation rates over successive balance perturbations in Parkinson's disease. Neuroscience 2012;217:123-129.

27. Visser JE, Oude Nijhuis LB, Janssen L, et al. Dynamic posturography in Parkinson's disease: diagnostic utility of the "first trial effect". Neuroscience 2010;168:387-394

28. Campbell AD, Squair JW, Chua R, Inglis JT, Carpenter MG. First trial and StartReact effects induced by balance perturbations to upright stance. J Neurophysiol 2013;110:2236-2245.

29. Fling BW, Gera Dutta G2, Horak FB. Functional connectivity underlying postural motor adaptation in people with multiple sclerosis. Neuroimage Clin 2015;8:281-289.
30. Kurtzke JF. Rating neurologic impairment in multiple sclerosis an expanded disability status scale (EDSS). Neurology 1983;33:1444-1452.

31. Jacobson GP, Shephard NT. Balance Function Assessment and Management. Second Edition. Plural Publishing, Incorporated, 2014.

32. Cattaneo D, Regola A, Meotti M. Validity of six balance disorders scales in persons with multiple sclerosis. Disabil Rehabil 2006;28:789-795.

33. Cattaneo D, Jonsdottir J, Repetti S. Reliability of four scales on balance disorders in persons with multiple sclerosis. Disabil Rehabil 2007;29:19201925 .

34. Sahin F, Yilmaz F, Ozmaden A, Kotevolu N, Sahin T, Kuran B. Reliability and validity of the Turkish version of the Berg Balance Scale. J Geriatr Phys Ther 2008;31:32-37.

35. Casadio M, Sanguineti V, Morasso P, Solaro C. Abnormal sensorimotor control, but intact force field adaptation, in multiple sclerosis subjects with no clinical disability. Mult Scler 2008;14:330-342.

36. Casadio M, Sanguineti V, Solaro C. A haptic robot reveals the adaptation capability of individuals with multiple sclerosis. I J Robotics Res 2007;26:1225-1233.

37. Gera G, Fling BW, Van Ooteghem K, Cameron M, Frank JS, Horak FB. Postural motor learning deficits in people with MS in spatial but not temporal control of center of mass. Neurorehabil Neural Repair 2016;30:722-730.

38. Nonnekes J, Scotti A, Oude Nijhuis LB, et al. Are postural responses to backward and forward perturbations processed by different neural circuits? Neuroscience 2013;245:109-120. 